\title{
Doing Site Selection Even if You Don't Want to Move and Attracting Customers to Your New Location
}

By Jeff Grandfield and Dale Willerton - The Lease Coach

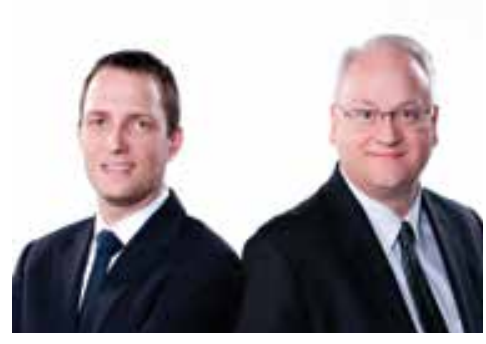

Dale Willerton is the founder of The Lease Coach and Jeff Grandfield recently joined him as partner. Dale and Jeff are commercial lease consultants who work exclusively for tenants, and are also professional speakers and co-authors of Negotiating Commercial Leases and Renewals For Dummies. Got a leasing question? Need help with your new lease or renewal?

Call1-800-738-9202,email DaleWillerton@TheLeaseCoach.com,orvisitwww.TheLeaseCoach. com. For a copy of our free CD, Leasing Dos \& Don'ts for Commercial Tenants, please email your request to DaleWillerton@TheLeaseCoach.com.

T ust one important message we share in our new book, Negotiating Commercial Leases \& Renewals FOR DUMMIES (Wiley, 2013) is the value of conducting site selection prior to negotiating a lease renewal. Typically, many years have gone by since you last looked at available commercial properties and it's time to do that again. The reason that so many optometry tenants resist doing this homework is they say that they don't have the time, or there isn't any good space for lease near them or they don't plan to move anyway, so why waste time looking at other locations?

What if we told you that two of your closest competitors were going to close out of business, move, expand, downsize or were struggling to stay open? Would this information change your lease renewal plans? Of course it would. What if you learned that a new competitor was coming into the neighbourhood? If your rent is going up and your sales are going down, that affects your decision-making process about a lease renewal.

Timing is critical when you request lease proposals from landlords and their listing agents. Ideally, The Lease Coach does all of your site selection at once and receives multiple proposals all within a few days, including any renewal proposal from your landlord. This allows us to compare the deals on paper side-by-side. Sometimes, a landlord's real estate agent sends a casual e-mail proposal, which is not as effective as a full proposal on their letterhead. If we want to show this competitor's lease proposal to your landlord to create stronger leverage for your renewal negotiations, it has more clout if it looks more official than a casual e-mail.

Remember to not assume that any of what you're doing is held confidential. The grapevine in commercial real estate is a thriving one, and if you want the real estate agent to keep the deal quiet, don't just tell them, ask them and confirm in writing they will keep it confidential.

Your strength or leverage may lessen the closer you get to the renewal option deadline or Lease Termination date, so the farther in advance we can find out what the landlord wants to do with your tenancy and rental rate, the more time you have to react. If you're going to get bad or disturbing news (in the form of a rental increase), you want that information sooner rather than later. Keep in mind that most landlords want and plan to have their tenants renew, so you're usually on the same page plan-wise anyway.

This also applies in cases where you don't have a renewal option and want to remain in your same location. The closer you get to the end of the term, the less relocation time you have and it becomes clearer to the landlord that you can't or don't intend to consider a relocation. There's also the peace-of-mind factor of putting the lease renewal to bed well in advance, if possible, as you want to plan renovations.

If you move into a new location, you will need to attract customers to visit your place of business. Just one method of doing this is by means of signage. It's much easier for customers to find your business if you have a prominent sign with your company's name on it out front of the property. The bigger, the better - and the more attractive, the better too!

Optometry tenants shouldn't just assume their landlord shares their vision of a large sign on or in front of his property. In fact, The Lease Coach has seen many tenant requests for more or larger signage often initially rejected by landlords. 
Landlords impose signage criteria and restrictions mainly because whatever they allow one tenant to do signage-wise, the other tenants will also want to do. Most commercial landlords prefer an uncluttered property without additional signage, simply because it looks more attractive. If your landlord does allow you to place a sign on the property, creating and maintaining it is your responsibility. Consider this fact carefully but know there are advantages to signage including the following:

Visibility: Signage makes your business easier to find for customers who are specifically looking for you. Obviously, if you're in an area with a sea of shopping plazas, a sign with your name on it makes it easier to pick you out of the crowd.

Customer Traffic: Shoppers who don't know you are there may be drawn in by your sign as they drive by.

Trust: Local residents who see your sign as they drive back and forth to work each day are eventually more likely to do business with you when the time comes.

When it comes to signage, optometry tenants can make many common mistakes. Beware of the following:

With pylon signage (the tall sign by the roadway that tells passers-by what tenants are in the plaza), tenants typically pay the landlord rent to advertise on the signs. Don't assume that you'll automatically get a sign panel. Keep an eye on what your landlord is currently charging for pylon signage as well as any provisions for increases or to terminate your signage rights. Don't let the lack of current pylon signage space stop you. The Lease Coach has successfully negotiated for the first right of refusal for any signage panel that may become available in the future.

Sidewalk sandwich boards and banners can be extremely useful for optometry tenants trying to attract business, but landlords may say, "no". The Lease Coach has negotiated predetermined times when the tenant can use these signs - for example, $4-6$ weeks in advance of busy "back-to-school" sales periods. We have found that landlords may be more comfortable knowing that these signs will not be out all year and, thereby, creating clutter (in a landlord's mind ...).

Understand that a commercial landlord typically sees signage as an extra rental income stream. By creating a pylon sign that has fewer panels than tenants in the building, the landlord can assure that demand is greater than supply - thus allowing the landlord to charge a substantial rent or monthly fee for these pylon signs.
You should also know that, when it comes to paying rent for signage, sometimes you're paying for both sides of the pylon sign. Sometimes that landlord may even try to charge you for fascia signage on the front of the building and (perhaps more desirable) electronic signage elsewhere (if your business has an illuminated signage board on the property).

If you're not sure whether you'll benefit from signage or how long you may want to be on the property's pylon signage, negotiate a right to terminate your signage rights and associated rent obligations. Make sure, however, that you understand whether the landlord has the right to increase signage rental rates or terminate your right to signage.

\section{Case Study}

Optometry tenants often get into trouble by assuming that signage will be free. The Lease Coach remembers one landlord who bought a building, noticed that all tenants had the right to have signage above their location, but also observed the landlord could charge for such signage. In this case, the landlord charged tenants for signage over their business doors. The tenants could remove this signage and avoid the monthly charges, but how would their customers identify their location?

For a copy of our free CD, Leasing Dos \& Don'ts for Commercial Tenants, please e-mail your request to DaleWillerton@TheLeaseCoach.com.

Dale Willerton and Jeff Grandfield - The Lease Coach are Commercial Lease Consultants who work exclusively for tenants. Dale and Jeff are professional speakers and co-authors of Negotiating Commercial Leases \& Renewals For Dummies (Wiley, 2013). Got a leasing question? Need help with your new lease or renewal?

Call 1-800-738-9202, e-mail DaleWillerton@TheLeaseCoach.com or visit www. TheLeaseCoach.com.

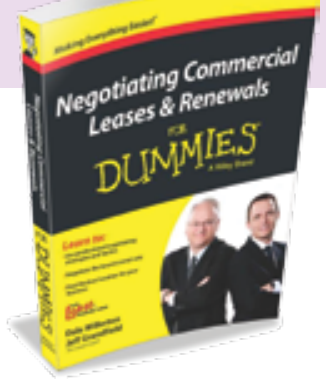

